\title{
The Synthesis of Carboxymethyl Chitosan-Pectin Film as Adsorbent for Lead (II) Metal
}

\author{
B. Hastuti, Mudasir, D. Siswanta, and Triyono
}

\begin{abstract}
The aim of this study was to develop a procedure for preparing film polyelectrolyte complex pectine/chitosan with increased sorption capacity for heavy metal ions which could be used as adsorbent to remove lead (II) ion in waste water. A film of the polyelectrolyte complex between chitosan and pectin were prepared by mixing the complex of both polysaccharides. Firstly, chitosan was grafted with acetate to form carboxymetyl chitosan (CMC). Subsequently, CMC is mixed with pectin to form $\mathrm{CMC} /$ pectin film. The result showed that the optimum mass ratio of CMC:pectin to synthesis CMC-Pectin film was $70: 30 \%$, optimum adsorbent mass to adsorb $\mathrm{Pb}$ (II) was $10 \mathrm{mg}$ with $70 \%$ of adsorption and adsorption capacity was $30.1 \mathrm{mg} / \mathrm{g}$. Optimum contact time to adsorb Pb (II) was 75 minutes with $87 \%$ of adsorption and adsorption capacity was $40.0 \mathrm{mg} / \mathrm{g}$. Optimum $\mathrm{pH}$ to adsorb $\mathbf{P b}$ (II) was at $\mathrm{pH} 5$ with $93 \%$ of adsorption and adsorption capacity was $42.7 \mathrm{mg} / \mathrm{g}$.
\end{abstract}

Index Terms-CMC, pectin, CMC-pectin film, adsorbent, lead (II) metal ion.

\section{INTRODUCTION}

The rapid industrial development and the using of various metallic materials have a negative impact, namely the emergence of cases of environmental pollution caused by waste containing heavy metals [1]. This pollution can cause harm and disturbing people who live around the industry. Refining metal factory, metal plating, painting and manufacture of battery are a source of heavy metal contaminants. Waste containing the remains of these heavy metals are dangerous if not be done properly and the processing is very harmful because it pollutes the environment especially with the nature of the toxicity.

Lead $(\mathrm{Pb})$ is one of the major pollutants that contaminate the environment. It happens because the main source of lead pollution is get from motor vehicle exhaust emissions. In addition there is also a lead in industrial wastewater in the production process to use lead, such as battery manufacturing industry, paint industry, and industrial ceramics. The presence of lead in the environment component of the water, soil, and air pollution allowed the development of the transmission became more widely to a variety of living things, including humans, causing health problems, such as the disruption of the synthesis of red blood, anemia, and

Manuscript received July 31, 2013; revised September 29, 2013.

B. Hastuti is with the Doctorate Program, Department of Chemistry, Faculty of Mathematics and Natural Sciences, Universitas Gadjah Mada, Yogyakarta. Indonesia (e-mail:bhastuti.uns@gmail.com).

Mudasir, D. Siswanta, and Triyono are with the Department of Chemistry, Faculty of Mathematics and Natural Sciences, Universitas Gadjah Mada, Yogyakarta, Indonesia. decreased intelligence in children [2]

Nowadays heavy metals are the environmental priority pollutants and are becoming one of the most serious environmental problems. So these toxic heavy metals should be removed from the wastewater to protect the people and the environment. Many methods that are being used to remove heavy metal ions include chemical precipitation, ion-exchange, adsorption, membrane filtration, electrochemical treatment technologies, etc [3]. Adsorption is one of the physicochemical treatment processes which found to be effective in removing heavy metals from aqueous solutions [4]. According to Bailey et al [5], an adsorbent can be considered as cheap or low-cost if it is abundant in nature, requires little processing and is a by-product of waste material from waste industry. Adsorption methods are generally based on the interaction of metal ions with functional groups that exist on the surface of the adsorbent through interaction and complex formation usually occurs on the surface of solids which have rich functional groups such as - $\mathrm{OH},-\mathrm{NH},-\mathrm{SH}$ and $-\mathrm{COOH}[6]$.

Pectin is one of the compounds found in plant cell walls mainland. Pectin, an anionic plant cell wall polysaccharide based on a-(1-4) linked D-galacturonic acid, is commercially extracted from pectin-rich sugar-beet pulp, apple pomace, and citrus peels [7]. All this time, the pectin was widely used in the food industry, pharmaceuticals and cosmetics. At these industries pectin is used primarily as a gelling material [8]. However, when considering that the structure of the pectin component also contains a lot of active groups, the pectin can also be used as a source biosorbent [9]. The main functional groups of pectin are hydroxyl, carboxyl, amide and methoxyl. These functional groups can be used to bind heavy metals, especially hydroxyl groups.

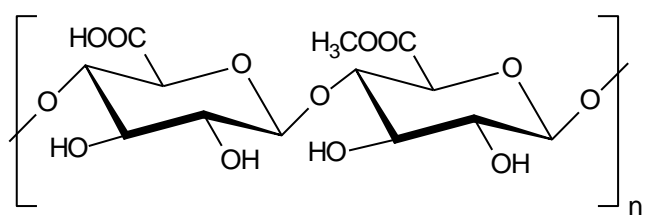

Scheme 1. Pectin structure.

Chitosan, a cationic copolymer of glucosamine and Nacetylglucosamine, is a partially deacetylated derivative of a natural polysaccharide - chitin, which is one of the most abundant carbohydrates in nature and is mostly derived from the exoskeleton of crustaceans [10]. Chitosan can be used as an adsorbent because it has amine and hydroxyl groups that can be used as an ion-exchanger, and can act as an adsorbent to adsorb heavy metals. Carboxymethyl chitosan (CMC) is one of the modified chitosan made through esterification process; the product is widely used in the pharmaceutical industry / healthcare and cosmetics. CMC is a water-soluble 
chitosan derivative forming semi permeable membranes and films [11].

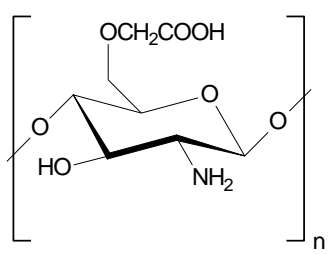

Scheme 2. Structure of carboxymethyl chitosan

Interactions occur between polyanions and polycations, leading to the formation of a polyelectrolyte complex (PEC). As a positively charged polysaccharide, chitosan has been incorporated with pectin to fabricate various composite materials [12] and [13]. In addition to ionic interactions, there are other types of interactions that can form between amino groups and carboxyl groups, such as hydrogen bonds and covalent bonds formed using specific conjugating chemicals, like 1-ethyl-3-(3-dimethylaminopropyl) carbodiimide (EDC) and N-hydroxysuccinimide (NHS) [14].

\section{MATERIALS AND METHOD}

\section{A. Materials}

The pectin used was obtained from local pectin from orange peels. And chitosan used was obtained from local chitosan from crab shell.

\section{B. Method}

Before use, a first modified chitosan, carboxymethyl chitosan with the workings of the following: Dissolve $3 \mathrm{~g}$ chitosan in $80 \mathrm{ml}$ of isopropanol. Add $28 \mathrm{~mL} \mathrm{NaOH} 40 \% \mathrm{w} / \mathrm{v}$ carefully by drops. Chitosan and isopropanol was stirred for 30 minutes.

Add as much as $7.65 \mathrm{~g}$ of chloroacetic acid, then stirred for 12 hours. The mixture was filtered and washed with ethanol. Dried sediment filtering results in an oven at $600 \mathrm{C}$ for $3 \mathrm{~h}$. g. Carboxymethyl chitosan derived functional group characterized using Infrared spectrophotometer. Once formed CMC, then combined with the following steps:

Dissolving $0.2 \mathrm{~g}$ of pectin in $10 \mathrm{ml}$ acetic acid $5 \% \mathrm{v} / \mathrm{v}$ were homogenized. CMC dissolving 0.2 grams of acetic acid in 10 $\mathrm{ml}$ of $5 \% \mathrm{v} / \mathrm{v}$ were homogenized. CMC and pectin gel mixed and stirred for $2 \mathrm{~h}$. and poured in a Petri dish and dried to the oven for 5 hours at $40{ }^{\circ} \mathrm{C}$. Add $5 \mathrm{ml}$ of $1 \mathrm{M} \mathrm{NaOH}$ and let stand for 12 hours. Washing the film with distilled water and then dried to the oven for 2 hours at $40{ }^{\circ} \mathrm{C}$. Obtained adsorbent functional group characterized by using infrared spectroscopy.

Synthesis of Film CMC-pectin is done by using a variation of the mass ratio CMC: pectin as in the following Table I.

TABLE I: VARIATION OF RATIO MASS CMC AND PECTIN

\begin{tabular}{cccc}
\hline Samples & $\begin{array}{c}\text { Mass ratio } \\
\text { CMC:pectin }\end{array}$ & $\begin{array}{c}\text { Mass of } \\
\text { CMC } \\
(\mathrm{g})\end{array}$ & $\begin{array}{c}\text { Mass of } \\
\text { Pectin } \\
(\mathrm{g})\end{array}$ \\
\hline A & $50 \%: 50 \%$ & 0,20 & 0,20 \\
B & $70 \%: 30 \%$ & 0,28 & 0,12 \\
C & $40 \%: 60 \%$ & 0,16 & 0,24 \\
D & $30 \%: 70 \%$ & 0,12 & 0,28 \\
E & $60 \%: 40 \%$ & 0,24 & 0,16 \\
\hline
\end{tabular}

Adsorption process is done with a variety of adsorbent mass, contact time, and $\mathrm{pH}$. A mass variation used were 5, 10, 15 and $20 \mathrm{mg}$. Variation of contact time used was 15, 30, 45, $60,75,90$, and 120 . While the $\mathrm{pH}$ variations used were $2,3,4$, $5,6,7$, and 8 . Initial concentration of $\mathrm{Pb}$ (II) was $50 \mathrm{ppm}$ by volume of $10 \mathrm{ml}$. Analysis of the adsorbed ion content determined by atomic absorption spectrophotometry.

\section{RESUlt AND DisCUSSION}

In this study used the absorbent material of pectin and chitosan, because it can be used as a biomaterial that can absorb the metal. Pectin has an active groups of carboxylic and chitosan amine groups. It is a very reactive material that can bind a metal by forming a complex compound. Composite pectin with chitosan forms stable polyelectrolyte complexes [15]. Interaction between active group COO- of pectin and active group $-\mathrm{NH}_{2}$ of chitosan complement the character of these macromolecules. Its complexes usually have a rigid structure that is very different from its original properties.

\section{A. Characterizations}

The film of pectin-CMC was prepared using the membrane method. The FTIR spectra of chitosan (Fig. 1a) show absorption peaks at $3464 \mathrm{~cm}^{-1}$ assigned to the $\mathrm{O}-\mathrm{H}$ stretching vibration. Width and shift absorption of wave number on -OH group is caused by the overlap - $\mathrm{NH}$ of the amine. Absorption band at $2877.79 \mathrm{~cm}^{-1}$ is the stretching vibration of $\mathrm{C}-\mathrm{H}$ group methylene and at $1026.13 \mathrm{~cm}^{-1}$ is the $\mathrm{C}-\mathrm{O}$ group. Another Uptake of chitosan look at wave numbers 1651.07 $\mathrm{cm}^{-1}$ indicate the presence of amide groups (-NHCO)[10] and [16]

Fig. 1b, CMC shows absorption of peaks IR spectra at wave numbers $3464.15 \mathrm{~cm}^{-1}$ which is the absorption of the -OH stretching vibration that overlap with the - NH stretching vibration absorption. Peak absorption of $\mathrm{CH}$ stretching vibration shifted from $2877.79 \mathrm{~cm}^{-1}$ to $2924.09 \mathrm{~cm}^{-1}$. Increasing the absorption peak of carbonyl bands (stretching $\mathrm{C}=\mathrm{O}$ ) at $1740 \mathrm{~cm}^{-1}$ indicates the addition of a carboxylic group (-COOH) which means it has been formed CMC. From all these data it can be concluded that it has formed CMC result of synthesize chitosan with chloroacetic acid [10] and [16].

FTIR spectra of pectin in Fig. 1c show a broad absorption band at $3387.00 \mathrm{~cm}^{-1}$, indicates the range of the $\mathrm{OH}$ group vibrations. Ribbon at $1064.71 \mathrm{~cm}-1$ is the stretching vibration of the-CO- Absorption at $1627.92 \mathrm{~cm}^{-1}$ is an absorption of group - $\mathrm{COOH}$ [17], [18] and [19]

Characteristics of film CMC-Pec using FTIR shows that it has an active force hydroxide $(-\mathrm{OH})$ indicated by the spectra with wave numbers $3464 \mathrm{~cm}^{-1}$ and the active carboxylic group (-COOH) at wave number $1635 \mathrm{~cm}^{-1}$ and bands related to $\mathrm{C}=\mathrm{O}$ stretching of the ester could be observed at $1751 \mathrm{~cm}^{-1}$ [20],[21] and [22].(Fig. $1 \mathrm{~d}$ ).

\section{B. Influence of Mass Ratios}

Fig. 2 shows the ratio mass between of pectin with CMC. From these Fig the optimum mass ratio between the pectin: CMC is $30 \%: 70 \%$ (Fig. B) showing the greatest intensity of 
absorption at a wavelength of $3400(-\mathrm{OH})$ and $1600(\mathrm{C}=\mathrm{O})$ and $1700\left(-\mathrm{OCH}_{3}\right)$.

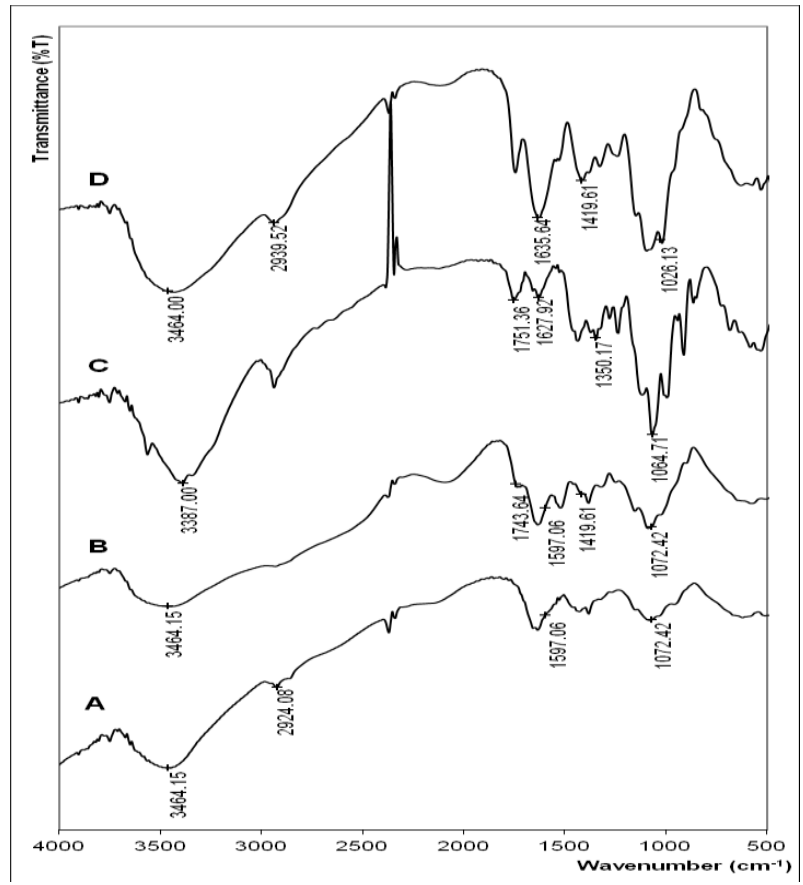

Fig. 1. FTIR spectra of film pec-CMC: a. chitosan, b. CMC, c. pectin, d. film pectin-CMC

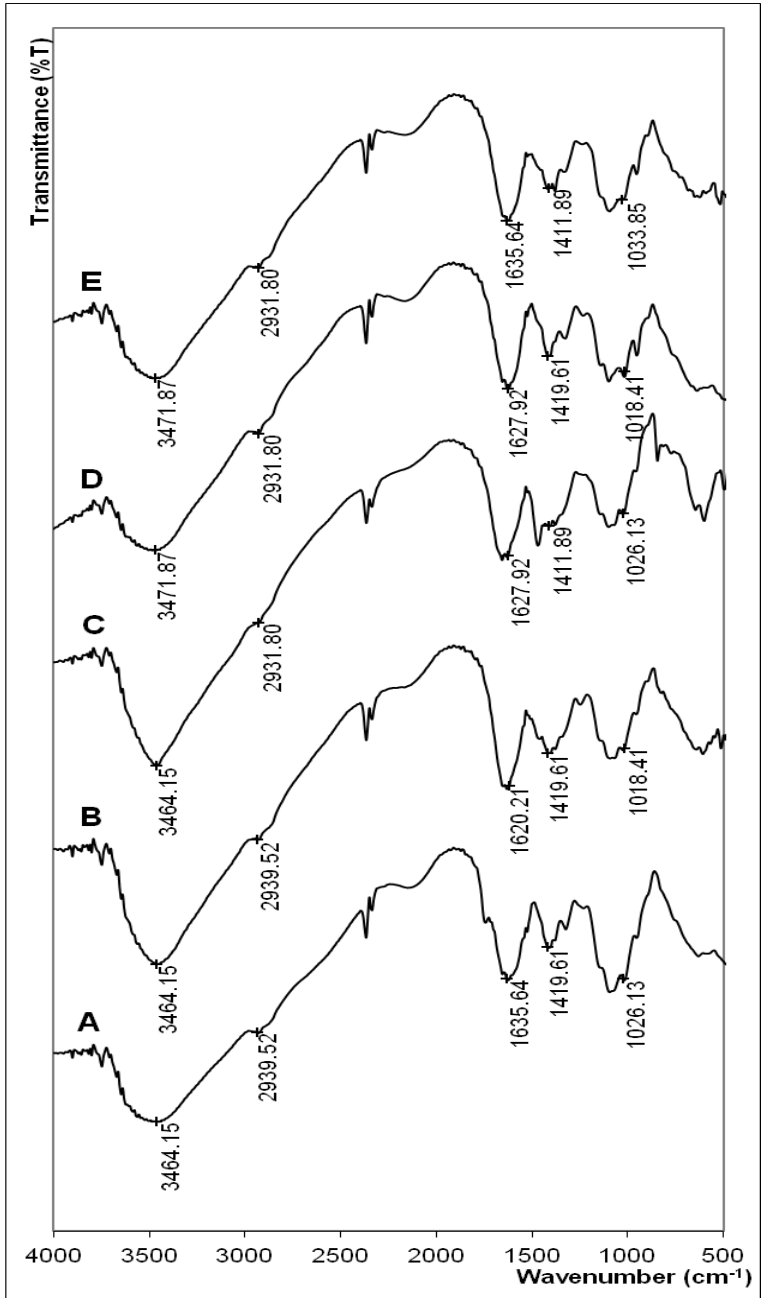

Fig. 2. FTIR spectra of \% ratio mass: CMC: pectin: A. 50:50; 70:30; 40:60; $30: 70 ; 60: 40$

\section{Determination of Optimum Adsorbent Mass}

The relationship between the mass of adsorbent upon adsorption capacity in Fig. 3 and percentage $\mathrm{Pb}$ (II) adsorbed show in Fig. 4. It shows at 5-10 $\mathrm{mg}$ adsorbent mass absorption levels are increasing rapidly due to the growing number of adsorbent process of diffusion and binding of the better adsorbate molecules and adsorbent mass reaches a maximum at $10 \mathrm{mg}$. At $10-20 \mathrm{mg}$ adsorbent mass absorption levels of $\mathrm{Pb}$ (II) adsorbents have decreased due to absorb maximum $\mathrm{Pb}$ (II) and the active adsorbent was no longer able to bind $\mathrm{Pb}$ (II). From this study, the optimum adsorbent mass obtained was $10 \mathrm{mg}$ with a metal ion concentration of $\mathrm{Pb}$ (II) adsorbed at $70 \%$ and the adsorption capacity of $30.16 \mathrm{mg} / \mathrm{g}$.

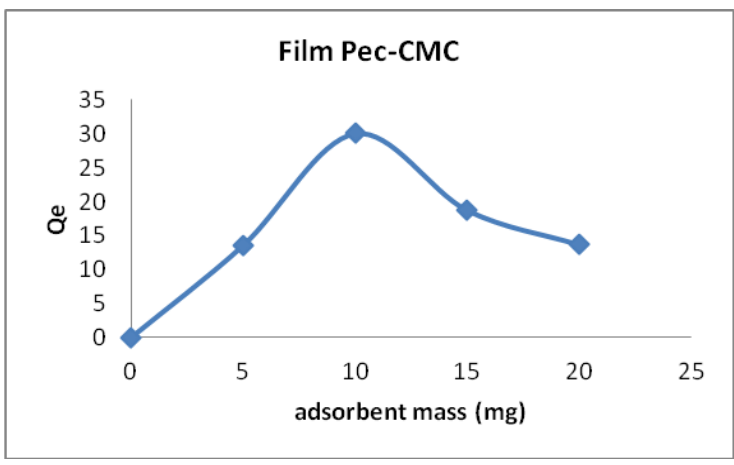

Fig. 3. Graph of adsorbent mass vs. adsorption affectivity.

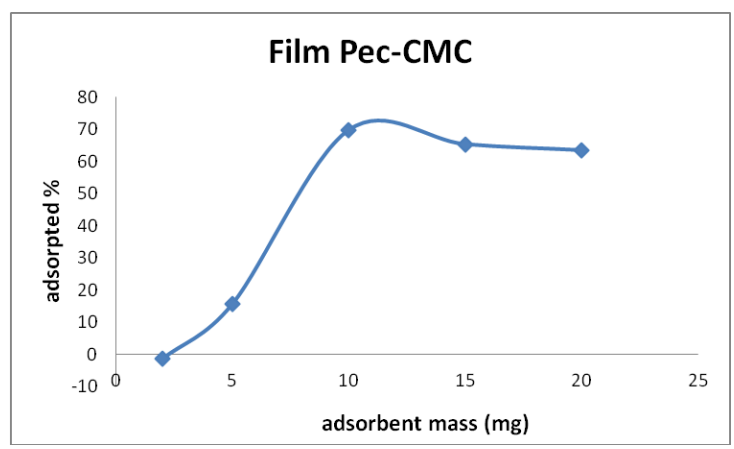

Fig. 4. Graph of mass adsorbent vs. \% adsorbed.

\section{Determination of Optimum Contact Time}

The graph of the relationship between the contact time of $\mathrm{Pb}$ (II) ion with adsorption capacity and \% adsorbed of film and is show in Fig. 5 and Fig. 6.

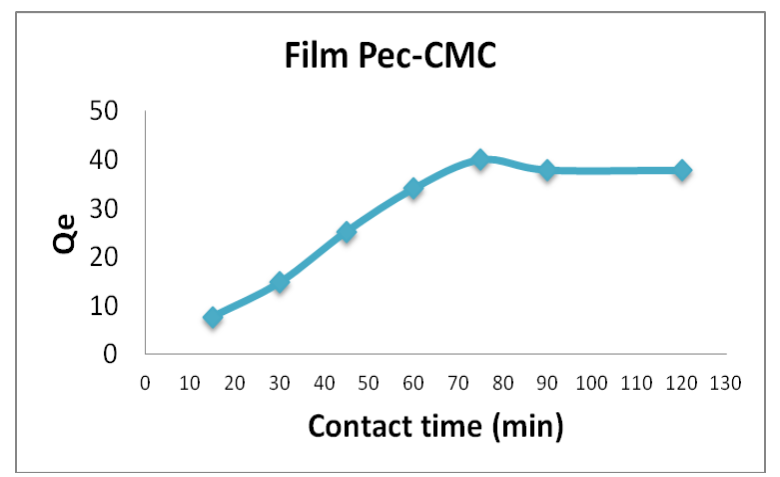

Fig. 5. The relationship between contact time of $\mathrm{Pb}$ (II) ion with adsorption capacity $(\mathrm{Q})$ 


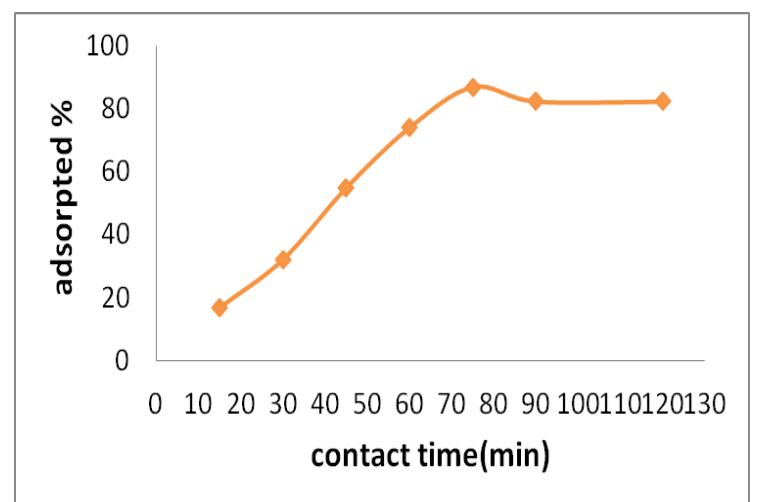

Fig. 6. The relationship between contact time of $\mathrm{Pb}(\mathrm{II})$ ion with $\%$ adsorbed

Contact time is important to determine of the adsorption process, because it allows better mechanism the diffusion process and binding of adsorbate molecules. Variation contact time used was 15, 30, 45, 60, 75, 90, and 120 minutes On $15^{\text {th }}$ minute, the film adsorbed $\mathrm{Pb}$ (II) ion with adsorption capacity of $7.75 \mathrm{mg} / \mathrm{g}$ and adsorption is $17 \%$. The binding process is going well with increasing time and then reached the optimum time in the $75^{\text {th }}$ minute with $87 \%$ absorption and adsorption capacity of $40.0 \mathrm{mg} / \mathrm{g}$. In the $75^{\text {th }}$ minute a perfect mixing occurs so that the films CMC-pectin can absorb $\mathrm{Pb}$ (II) optimally. After 75 minutes into a decline due to desorption the metal ion adsorbents release that $\mathrm{Pb}$ (II) which has been adsorbed because the pores of adsorbent was saturated by the $\mathrm{Pb}$ (II).metal ions

\section{E. Determination of Optimum $\mathrm{pH}$}

Fig. 7 and Fig. 8 show the relationship between $\mathrm{pH}$ solution vs. adsorption capacity and the percentage of $\mathrm{Pb}$ (II) adsorbed.

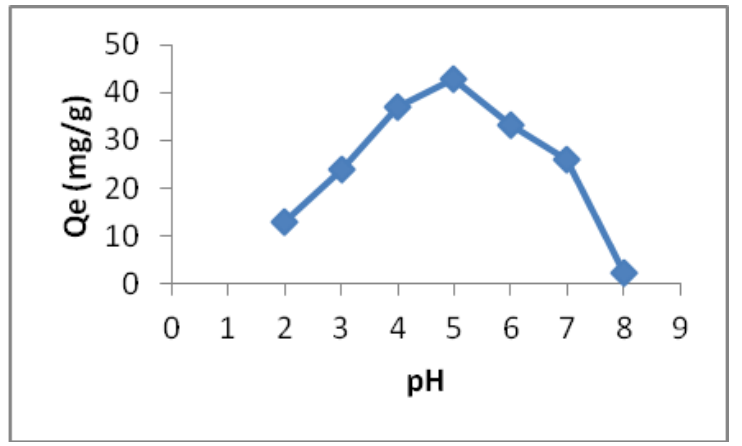

Fig. 7. Graph of the relationship between $\mathrm{pH}$ solution vs. adsorption capacity

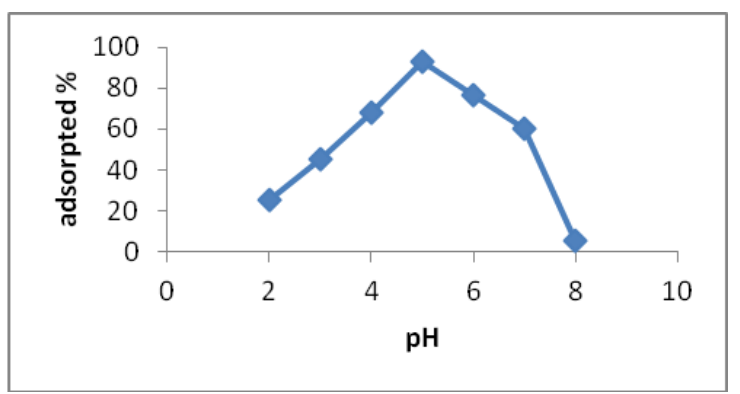

Fig. 8. Graph of the relationship between $\mathrm{pH}$ solution vs. percentage of $\mathrm{Pb}$ (II) adsorbed

The degree of acidity or $\mathrm{pH}$ of the solution is one of the important factors that determine the performance of the adsorbent in the adsorption process $\mathrm{pH}$ value is too low or too high will make optimum adsorbent unable to work. From Fig. 7 and 8 obtained results that on $\mathrm{pH} 2$ adsorption percentage of the film is $25.1 \%$ with adsorption capacity is $13.0760 \mathrm{mg} / \mathrm{g}$. Meanwhile, the percentage of adsorption tends rise on $\mathrm{pH} 3$. The $\mathrm{pH} 5$ is the optimum condition, in which the percentage of $\mathrm{Pb}$ (II) absorbed is $93 \%$ and the adsorption capacity is 42.7 $\mathrm{mg} / \mathrm{g}$. Furthermore at $\mathrm{pH} 6$, the adsorption percentage decreased to $76.5 \%$ and the adsorption capacity is $33.4 \mathrm{mg} / \mathrm{g}$. It is caused of the condition that higher $\mathrm{pH}$, the solution have more - $\mathrm{OH}$ ions in the solution. The existence of these ions causes $\mathrm{Pb}$ (II) ions are hydrolyzed and forms $\mathrm{Pb}(\mathrm{OH})_{3}$. The percentage adsorption decreases sharply when the $\mathrm{pH}$ is raised back to 8 , in which the obtained percentage adsorption is $5.4 \%$ and adsorption capacity is $2.1 \mathrm{mg} / \mathrm{g}$.

\section{F. Films Pectin-CMC as Adsorbent of Pb(II) Metal Ion}

CMC-pectin film potentially enough to be used as an adsorbent because of the active group - $\mathrm{OH}$ and $-\mathrm{COOH}$. It can interact with components of the adsorbate. Adsorption Film toward $\mathrm{Pb}$ (II) metal ion occurs between the $-\mathrm{COOH}$ groups of pectin and $\mathrm{CMC}$ with $\mathrm{Pb}$ (II) metal ions by chelating agent reaction as shown Fig. 3:
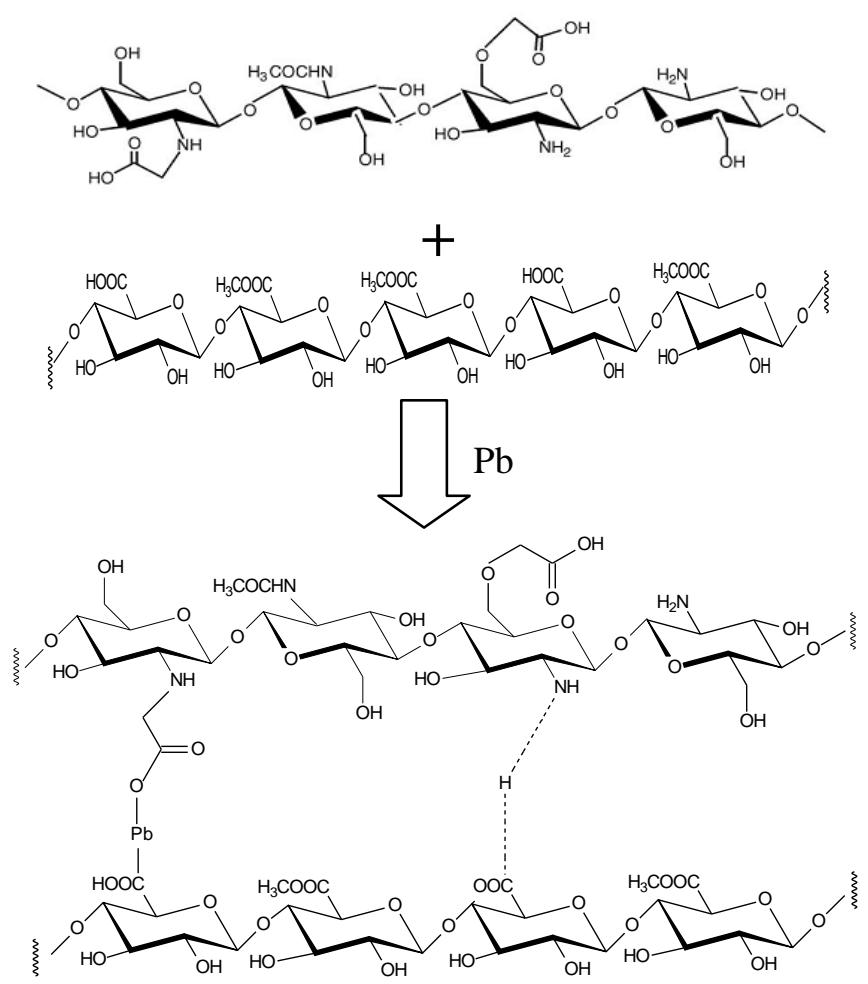

Scheme 3. The reaction of $\mathrm{Pec}-\mathrm{CMC}$ bonded $\mathrm{Pb}$ metal ion

\section{CONCLUSION}

Film of the Polyelectrolyte complex between chitosan and pectin were prepared by mixing the complex of both polysaccharides. Firstly chitosan was grafted with acetate to form a carboxymetyl chitosan (CMC) to increase active group as adsorbent. CMC mix with pectin to form polyelectrolyte film CMC/pectin Film pectin/chitosan able to increase sorption capacity for heavy metal ions which could 
be used as adsorbent to remove $\mathrm{Pb}$ (II) ion in waste water compared by chitosan or pectin separately.

\section{ACKNOWLEDGMENT}

The authors would like to thank Directorate General of Higher Education (DGHE), Department of National Education Republic Indonesia for to support.

\section{REFERENCES}

[1] N. Das, R. Vimala, and P. Karthika, "Biosorption of Heavy Metal," Indian Journal of Biotechnology, vol. 7, no. 4, pp. 159-169, 2008

[2] E. Naria, "Mewaspadai Dampak Bahan Pencemar Timbal (Pb) di Lingkungan Terhadap Kesehatan,” Jurnal Komunikasi Penelitian, vol. 17, no. 4, pp. 66-72, 2005

[3] F. L. Fu and Q. Wang, "Removal of heavy metal ions from wastewaters A review," Journal of Environmental Management, vol. 92, pp. 407-418, 2011

[4] M. M. Fares, Y. R. Tahboub, S. T. Khatatbeh, and Y. M. A. Haija, "Eco-Friendly, Vascular Shape and Interpenetrating Poly (Acrylic Acid) Grafted Pectin Hydrogels; Biosorption and Desorption Investigations," J Polym Environ, vol. 19, pp. 431-439, 2015.

[5] S. E. Bailey, T. J. R. M. Olin, Bricka, and D. D. Adrian, Water Res, vol. 33, pp. 2469,1999

[6] W. Stumm and J. J. Morgan, Aquatic Chemistry, $3^{\text {nd }}$ edition, Canada: John Wiley and Sons, Inc, 1996

[7] C. M. G. C Renard, M. J. Crepeau, and J. F. Thibault, "Structure of repeating units in the rhamnogalacturonic backbone of apple, beet and citrus pectins," Carbohydrate Research, vol. 275, pp. 155-165,1995

[8] M. S. Rodriguez, A. L. Zalba, and E. A. Debbaudt, "New Chitosan-Calcium Pectinate Pellets and Their Adsorption Capacity," $J$. Colloid. Polym., vol. 285, pp. 119-124, 2006

[9] Y. N. Mata, M. L. Blázquez, A. Ballester, F. González, and J. A. Mũnoz, "Sugar-Beet Pulp Pectin Gels As Biosorbent For Heavy Metals: Preparation and Determination Of Biosorption and Desorption Characteristics," Chemical Engineering Journal, vol. 150, pp. 289-301, 2009.

[10] V. K. Mouryaa, N. N. Inamdara, and A. Tiwarib, "Carboxymethyl chitosan and its applications," Adv. Mat. Lett., vol. 1, no. 1, pp. 11-33, 2011

[11] F. R. D. Abreu and S. P. C Filho, "Preparation and Characterization of Carboxymethylchitosan," Polímeros: Ciência e Tecnologia, vol. 15, no. 2, pp. 79-83, 2005

[12] M. Z. Elsabee, E. S Abdou, K. S. A Nagy, and M. Eweis, "Surface modification of polypropylene films by chitosan and chitosan/pectin multilayer," Carbohydrate Polymers, vol. 71, no. 2, pp. 187-195, 2008
[13] M. Hiorth, T. Versland, J. Heikkila, I. Tho, and S. A. Sande, "Immersion coating of pellets with calcium pectinate and chitosan," International Journal of Pharmaceutics, vol. 308, no. 1-2, pp. 25-32, 2006

[14] L. Richert, F. Boulmedais, P. Lavalle, J. Mutterer, E. Ferreux, G. Decher, "Improvement of stability and cell adhesion properties of polyelectrolyte multilayer films by chemical cross-linking," Biomacromolecules, vol. 5, no. 2, pp. 284-294, 2004

[15] S. S. Rashidova, R. Y. Milusheva, L. N. Semenova, M. Y. Janova, N. L. Voropaeva, Vasilyeva, S. Faizieva, and I. N. Ruban, "Characteristics of interactions in the pectin-chitosan," Sys. Chromatogr., vol. 59, pp. 779-782, 2004

[16] E. Ardelean, R. Nicu, D. Asandei, and E. Bobu, "Carboxymethyl-Chitosan As Consolidation Agent For Old Documents On Paper Support," European Journal of Science and Theology, vol. 5, no. 4, pp. 67-75, 2009.

[17] J. Lim, J. Yoo, S. Ko, and S. Lee, "Extraction and characterization of pectin from Yuza (Citrus junos) pomace: A comparison of conventional-chemical and combined physicaleenzymatic extractions," Food Hydrocolloids, vol. 29, pp. 160-165, 2012.

[18] W. W. Wai, F. M. Abbas, A. Karkhi, and A. M. Easa, "Comparing Biosorbent Ability of Modified Citrus and Durian Rind Pectin," Carbohydrate Polymers, vol. 79, pp. 584-589, 2010.

[19] A. Kumar and G. S. Chauhan, "Extraction and Characterization of Pectin from Apple Pomace and Its Evaluation as Lipase (Steapsin) Inhibitor," Carbohydrate Polymer, vol. 82, pp. 454-459, 2010.

[20] F. Bigucci, B. Luppi, M. S.Cerchiarac, G. L. Bettinetti, and R. V. Zecchia, "Chitosan/pectin polyelectrolyte complexes: Selection of suitable preparative conditions for colon-specific delivery of vancomycin," J. Pharm. Sci., vol. 35, pp. 435-441, 2008

[21] A. Ghaffari, K. Navaee, M. Oskoui, A. Bayati, and M. R Tehrani, "Preparation and characterization of free mixed-film of pectin/chitosan/Eudragit_ RS intended for sigmoidal drug delivery," $J$. Pharm and Biopharm, pp. 175-186, 2007

[22] C. Bernabe, W. Peniche, and A. Monal, "Swelling behavior of Chitosan/Pectin Polyelectrolyle Complex Membrannes, Effect of Thermal Cross-linking," Polym. Bull., vol. 55, pp. 367-375, 2005

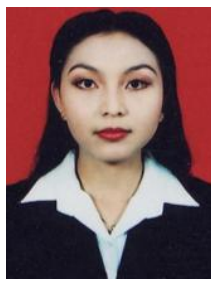

B. Hastuti was born in Sukoharjo, (Indonesia) on 06th August, 1978. She received his master's degree in Analytical Chemistry from the Universitas Gadjah Mada, Indonesia. At present, she is doing Ph.D. in Department of Chemistry, FMIPA, Universitas Gadjah Mada under the supervision of Prof, Dr. Mudasir, M.Eng., Dr. Dwi Siswanta, and Prof. Dr. Triyono, SU. Her area of interest is natural polymer material. 